Vol. 7(6) pp. 201-207, June, 2013

DOI: $10.5897 / A J P S 11.186$

ISSN 1996-0824 (C2013 Academic Journals

African Journal of Plant Science

http://www.academicjournals.org/AJPS

Full Length Research Paper

\title{
Conservation status of trees in Tehsil Takht-e-Nasratti, Karak Pakistan
}

\author{
Musharaf Khan $^{1 \star}$, Farrukh Hussain ${ }^{1}$ and Shahana Musharaf ${ }^{2}$ \\ ${ }^{1}$ Department of Botany, University of Peshawar, Pakistan. \\ ${ }^{2}$ Department of Chemistry, Government Girls Degree College S. Malton, Mardan, Pakistan.
}

Accepted December 20, 2011

\begin{abstract}
The present study documents the conservation status of 21 trees belonging to 14 families on small scale in Tehsil Takht-e-Nasrati, Karak through field surveys, frequently conducted in spring, summer and winter 2009-2010. Among these nine species were found to be rare, vulnerable (six species), infrequent (3 species), endangered (one specie) and dominant (two species). The conservation status of plants is determined according to IUCN 2001, Red Data List Categories and Criteria. After two years extensive field studies on the basis of questioner and personal observation including availability of plant, collection of plant, growth of plant, plant parts, population size, geographic range and habitat we concluded that Salvadora oleoides is endangered (EN) species.
\end{abstract}

Key words: Conservation, Tree species, Takht-e-Nasrati, Pakistan.

\section{INTRODUCTION}

The conservation status of organisms indicates whether the group is still extant or not and if yes, how likely the group is to become extant in the near future. Conservation status of a species depends upon many factors like grazing, fuel demand, agriculture land, deforestation, breeding success rates and known threats. Based on the sample of species that have been evaluated through 2006, the percentage of endangered species, that is, $40 \%$ of all organisms have been calculated by the International Union for Conservation of Nature (IUCN) (Anonymous, 2008). Habitat loss and degradation, introduction of alien species, pollution and diseases, over-exploitation and climate change are some threats faced by plants which are an integral part of our ecosystem because native plants are key components of the global biological diversity (Sudhersan et al., 2003).

It is estimated that some 270,000 to 425,000 vascular plant species are already known (Govaerts, 2001) with perhaps a further 10 to $20 \%$ still to be discovered and described (Hawksworth and Kalin-Arroyo, 1995). Pakis- tan's scenario is not different from the rest of the world. Plant biodiversity is also under tremendous pressure due to its population explosion, unplanned urbanization, deforestation and over-exploitation of natural resources. Unfortunately, very little work has been done on threatened plants of Pakistan and extremely limited information is available on this subject (Alam and Ali, 2009). According to Nasir (1991), 580-650 flowering plant species (that is, 12\%) are expected to be threatened. Chaudhri and Qureshi (1991) reported 709 taxa as threatened plants from Pakistan. However, both these studies are mainly based on field observation and literature, without any support of quantitative data. In contrast, in the recent red list of IUCN (Anonymous, 2008), only 19 flowering plants species have been listed from Pakistan. Regarding Pakistan, previous workers have classified the plant species as threatened or rare on the basis of literature or herbarium specimen. No work has been done according to IUCN red list categories or criteria (Anonymous, 2001) except Alam and Ali (2009), 


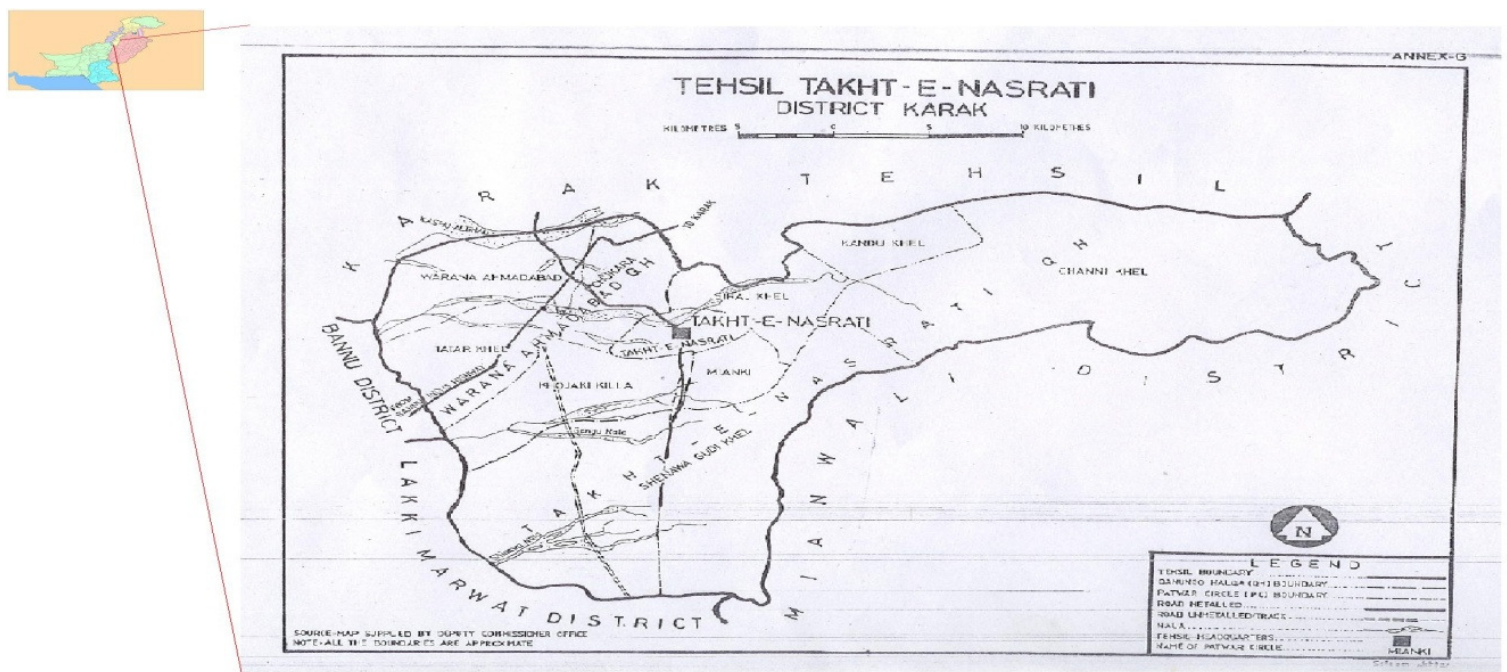

Figure 1. Map of Tehsil Takht-e-Nasrati, Karak.
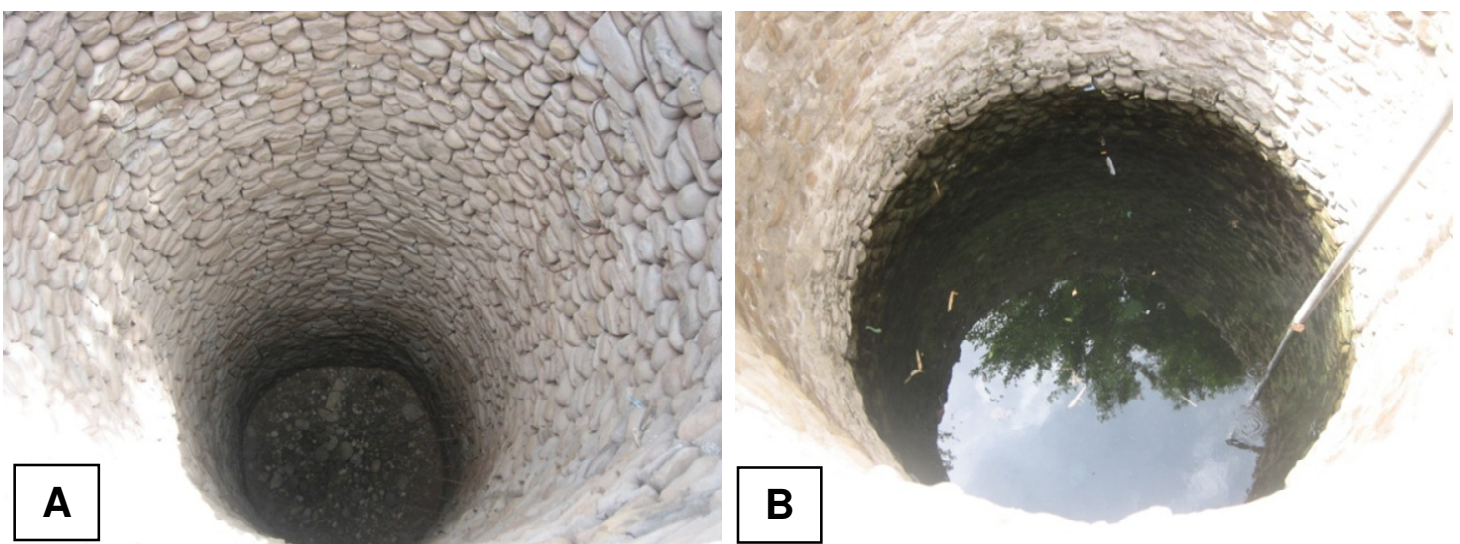

Figure 2. a. The lesser the vegetation the greater depth of wells. b. Deepening of well due to low water table.

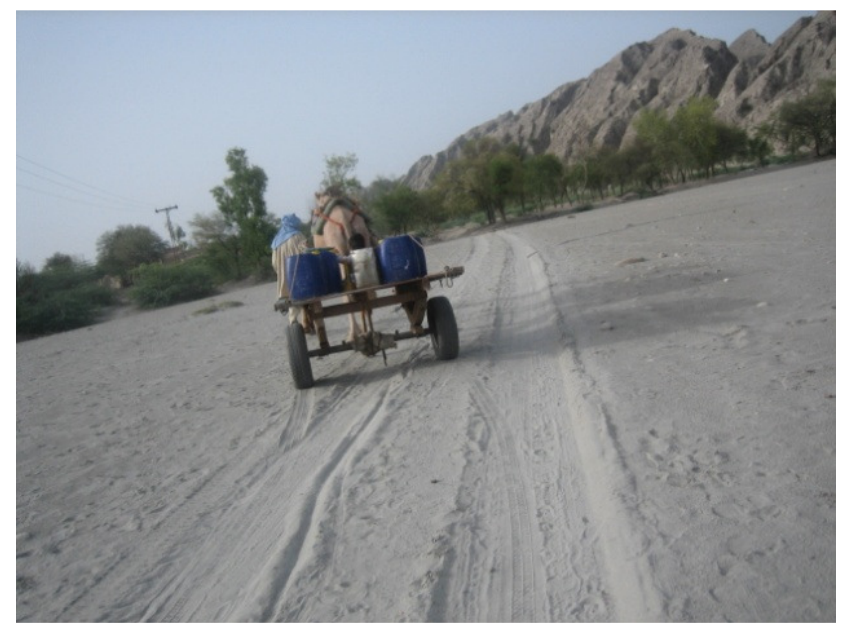

Figure 3. In search of water that become extinct due to use of natural resource. who classified Astragalus gilgitensis as a critically endangered (CR).

The Tehsil Takhti Nasratti is situated at $32.47^{\circ}$ to $33.28^{\circ}$ North and $70.30^{\circ}$ to $71.30^{\circ}$ East. The Tehsil is bounded by Tehsil Banda Dawood Shah on the North West, Tehsil Karak on the North East, District Mianwali and District Lakki Marwat on the South East, and Tribal area Adjoining District Bannu on the South West (Figure 1). The total area of Tehsil is about $613.66 \mathrm{~km}^{2}$. Majority of the area consists of rigged dry hills and rough fields areas that is, $323.97 \mathrm{~km}^{2}$ and agriculture land is about $289.7 \mathrm{~km}^{2}$. The area is situated at $340 \mathrm{~m}$ above the sea level. The major problem of the area is shortage of drinking water and over grazing (Figure 2). The people bring drinking water from the remote area (Figure 3). In the year 2001 to $2010,121.6 \mathrm{~mm}$ of rainfall per 10 years was recorded. The area is very hot in summer and very cold in winter. June and July are the hottest months, 
Table 1. Climatic data of Tehsil Takht-e-Nasratti for the year 2001-2010.

\begin{tabular}{|c|c|c|c|c|c|c|c|}
\hline \multirow{2}{*}{ Month } & \multicolumn{2}{|c|}{ Temperature $\left(\mathbf{C}^{\circ}\right)$} & \multicolumn{2}{|c|}{ Humidity (\%) } & \multirow{2}{*}{$\begin{array}{c}\text { Rainfall } \\
(\mathrm{mm})\end{array}$} & \multirow{2}{*}{$\begin{array}{c}\text { Soil } \\
\text { temperature } \\
\left({ }^{\circ} \mathrm{C}\right) \text { average }\end{array}$} & \multirow{2}{*}{$\begin{array}{c}\text { Wind speed } \\
\text { (km per } \\
\text { hour) }\end{array}$} \\
\hline & Max & Min & Max & Min & & & \\
\hline January & 19.18 & 4.26 & 75.80 & 35.24 & 27.43 & 7.03 & 2.9 \\
\hline February & 21.69 & 7.29 & 77.39 & 42.23 & 37.72 & 9.14 & 3.2 \\
\hline March & 28.20 & 12.06 & 75.38 & 35.23 & 37.17 & 13.89 & 3.5 \\
\hline April & 34.74 & 17.94 & 66.12 & 29.42 & 36.54 & 19.02 & 5.2 \\
\hline May & 38.32 & 22.33 & 59.66 & 30.73 & 31.6 & 21.87 & 5.4 \\
\hline June & 39.50 & 25.9 & 59.96 & 32.89 & 74.24 & 25.78 & 5.5 \\
\hline July & 38.44 & 25.76 & 73.33 & 38.76 & 121.6 & 26.77 & 5.2 \\
\hline August & 36.66 & 25.29 & 75.68 & 42.61 & 108.3 & 26.37 & 4.1 \\
\hline September & 35.47 & 21.95 & 77.21 & 39.29 & 61.58 & 23.49 & 3.7 \\
\hline October & 32.33 & 16.79 & 71.55 & 35.51 & 15.13 & 20.09 & 3.5 \\
\hline November & 26.71 & 10.01 & 71.56 & 36.66 & 5.80 & 14.10 & 3.2 \\
\hline December & 21.93 & 5.67 & 75.20 & 35.90 & 15.38 & 8.96 & 3.1 \\
\hline Mean & 31.1 & 16.27 & 71.57 & 36.21 & 47.71 & 18.04 & 4.04 \\
\hline
\end{tabular}

Source: Agricultural Research Farm Ahmadwala Karak.

whereas December and January are the coldest months. In the year 2001 to 2010 the mean maximum temperature was $39.5^{\circ} \mathrm{C}$, in the month of the June, where as the mean minimum temperature was as low as $4.26^{\circ} \mathrm{C}$ in the month of January (Table 1).

\section{MATERIALS AND METHODS}

\section{Field survey}

The study was conducted by frequently surveying in winter, spring and summer during 2009 to 2010 . The area is divided into plain and mountain. Habit, habitat, altitudinal range, population size, distribution range, impacts of multiple threats like habitat destruction, erosion, fuel wood cutting, grazing, poultry farms and invasive species have been studied for two years in the habitat.

\section{Plant collection and determination}

Plant specimens were collected from different parts of Tehsil Takhte-Nasrati. The population size was determined by counting the mature individuals. The seedlings were also counted separately. Nature of habitat was analysed by soil erosion, invasive species and impacts of anthropogenic activities.

\section{Questioner development}

Information on demographic (age, gender) and conservation status was gathered from each site by using a semi-structured questionnaire. Information about the availability of plant, collection of plant, growth of plant, plant parts that is, root, stem etc, local uses of the species as medicinal, fuel wood, timber and fodder etc. were obtained through random sampling by interviewing 600 respondents from different ages and gender. During survey personal observation was also recorded. Analysis of data was made with the help of group discussions and questioners among different age classes of Takht-e-Nasratti that include both genders of the society. The data was classified, tabulated, analyzed and concluded for final report.

\section{Conservation classes}

The plants were divided into five classes on basis of conservation status that is:

1) Endangered species: These species are few in number in the area due to environmental factors and they may be at risk.

2) Vulnerable species: These species are unprotected against attack in the area.

3) Rare species: These species are very uncommon in the area.

4) Infrequent species: These species are common in the area.

5) Dominant species: These species are very common in the area.

\section{RESULTS}

In the present study, the conservation status of trees was determined in Tehsil Takht-e-Nasrati. A total of 21 species belonging to 14 families were found (four Mimosaceae, two Moraceae, Myrtaceae, Rhamnaceae and Tamaricaea, and Caesalpinaceae, Capparidiaceae, Celastraceae, Meliaceae, Palmae, Papilionaceae, Punicaceae, Salvadoraceae and Sapotaceae with single species (Table 2). The plants were divided on the basis of conservation into five classes that is, endangered, vulnerable, rare, infrequent and dominant. In the present investigation the nine species were found to be rare, vulnerable (six species) Infrequent (three species), dominant (two species) and a single species was endangered.

\section{DISCUSSION}

The area is mostly divided into hilly area, sandy soils, 
Table 2. Floristic list and conservation status of tree in Takht-eNasrati.

\begin{tabular}{lllllll}
\hline \multirow{2}{*}{ Species name } & \multirow{2}{*}{ Family } & \multicolumn{3}{c}{ Conservation class } \\
\cline { 2 - 7 } & & End & Vul & R & Inf & Dom \\
\hline Acacia modesta Wall. & Mimosaceae & - & - & - & + & - \\
Acacia nilotica (L.) Delice. & Mimosaceae. & - & - & - & + & - \\
Albizia lebbeck (L.) Benth. & Capparidiaceae & - & - & & + & - \\
Capparis deciduas (Forssk). Edge worth. & Papilionaceae & - & - & + & - & - \\
Dalbergia sissoo Roxb. & Myrtaceae & - & - & + & - & - \\
Eucalyptus globules L. & Myrtaceae & - & - & + & - & - \\
Eucalyptus lanceolatus L & Celastraceae & - & + & & - & - \\
Gymnosporia royleana Wall. & Meliaceae. & - & & + & - & - \\
Melia azedarach L. & Sapotaceae. & - & + & - & - & - \\
Monotheca buxifolia (falk) A.DC. & Moraceae & - & + & - & - & - \\
Morus alba L. & Moraceae & - & - & + & - & - \\
Morus nigra L. & Caesalpinaceae & - & + & & - & - \\
Parkinsonia aculeate L. & Palmae & - & - & + & - & - \\
Phoenix dactylifera L. & Mimosaceae & - & - & - & - & + \\
Prosopis juliflora (Sw.) DC. & Punicaceae & - & - & + & - & - \\
Punica granatum L. & Salvadoraceae. & + & - & & - & - \\
Salvadora oleoides Decne. & Tamaricaea & - & + & & - \\
Tamarix aphylla (L.) Karst. & Tamaricaea & - & + & & - & - \\
Tamarix decidua Roxb. & Rhamnaceae & - & - & & - \\
Zizyphus maurtiana Lam. & Rhamnaceae & - & - & + & - \\
Zizyphus oxyphylla Edgew & - & - & - & - \\
\hline
\end{tabular}

End, Endangered; Vul, vulnerable; R, rare; Inf, infrequent, Dom, dominant.

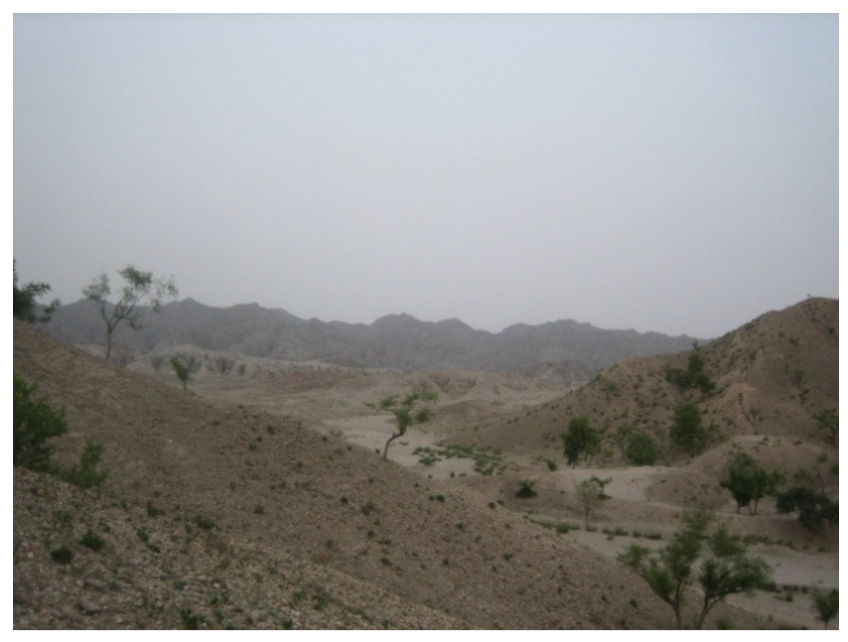

Figure 4. Gully erosion is common in area excessive.

river banks and plain with limestone silt. From the present investigation, it is noticed that each species have confined to a narrow distribution range and specific habitat. With the changes in environment, the plant species habitats are disturbed. A large scale stone excavation and road construction activity is the major cause of disturbance and destruction in the habitat of plant in the area. Gully erosion (Figure 4) was causing a severe damage during rains, individuals of plants species growing in sandy and river bank were found more prone to erosion than the plants found on rocky slopes and cliffs. Our observations agree with the workers (Myers, 1988) who reported the species from almost similar habitats from other parts of the world.

The invasion of invasive species was a great ecological problem to change habitat in the plain area. In Takht-eNasrati, Prosopis juliflora was found as invasive species. According to Huston, (1994) the invasion of invasive species is widely considered as second greatest cause of species endangerment and extinction after habitat loss around the globe. However, concentration of the population of invasive species was mostly found on plain areas rather than hilly areas (Figure 5). According to Pallewatta et al. (2003), due to devastating effects of $P$. juliflora, it has been included in the IUCN's list of 100 world's worst invasive species. According to El-Keblawy and Al-Rawai (2007) P. juliflora is causing extirpation of the native flora, resulting in the reduction of species richness and diversity. Noor et al. (1995) reported that $P$. juliflora plays a vital role in Pakistan in the elimination of natural vegetation due to its allelopathic effects.

The most ecological problem in the area is dryness. The area is very hot in summer and cold in winter. The rain is very scanty in the area (Table 1 ). Due to dryness, 


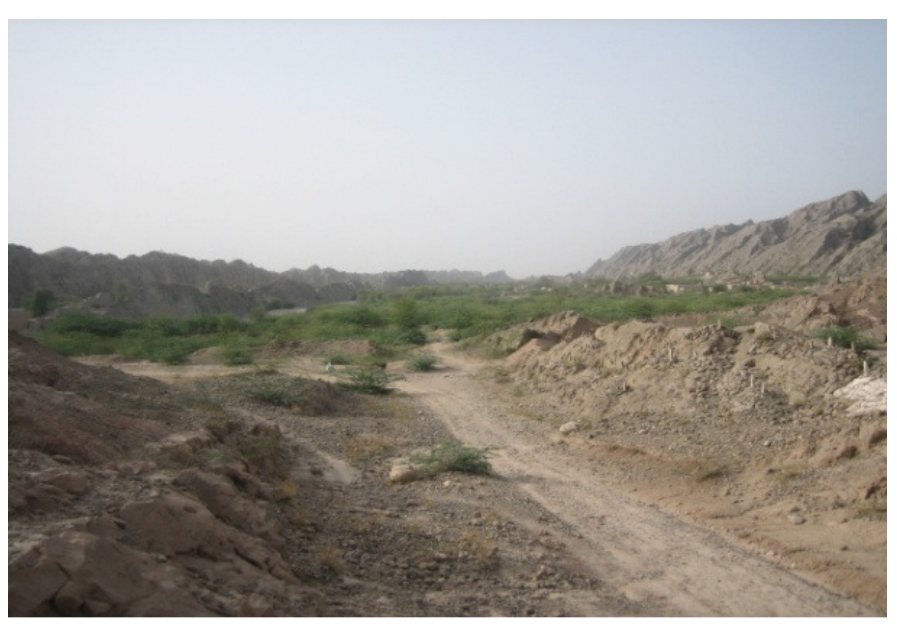

Figure 5. Prosopis juliflora was found as invasive species in plain.

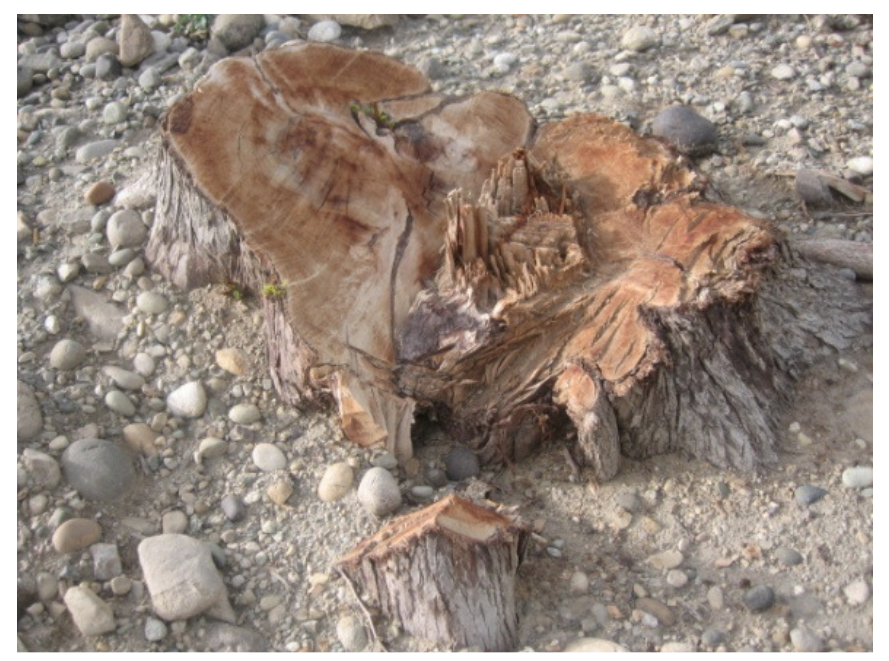

Figure 6. Cutting of trees so bad for growth.

the herbs species are very rare because the plants cannot grow to their reproductive stage in the area and the animal directly depend upon the tree species. According to Baggs and Maschinski (2000), population size is often affected by dry periods during the growing season, when plants may not produce any viable seed and there will be no natural recruitment. No natural recruitment was observed in Salvadora oleoides during the present studies. Hence, it is concluded that the population sizes of rare trees are continuously reducing at an alarming rate, without having natural recruitment.

Cutting of trees was ecological problem in the area due to the demand of fodder and fuel wood. The people of the area are very poor and due to unavailability of natural gas, the local communities depend upon the native tree for both purposes (Figure 6). According to (Hirway and Goswami, 2007; Engler, 2008), over-exploitation of plant species for fodder and fuel wood purpose by local

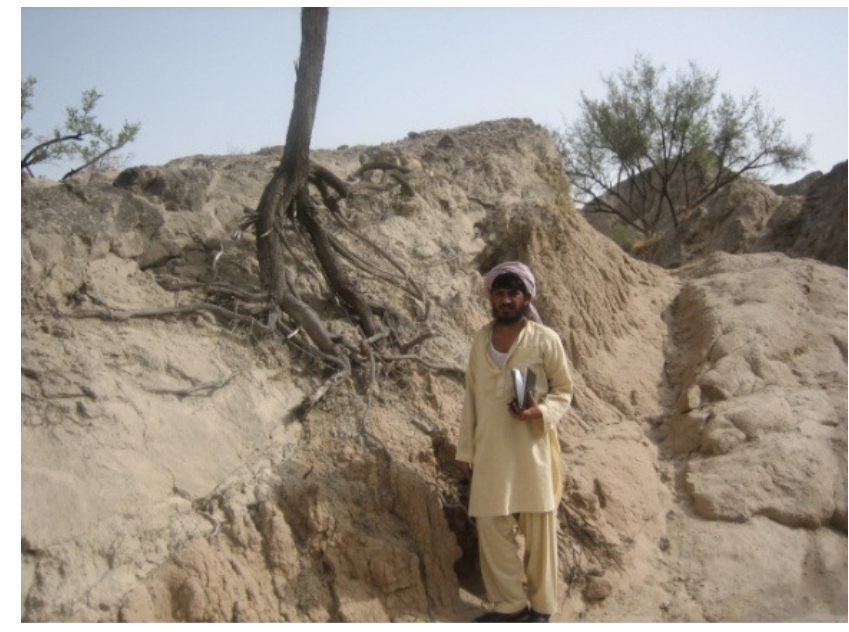

Figure 7. Soil erosion due to deforestation.

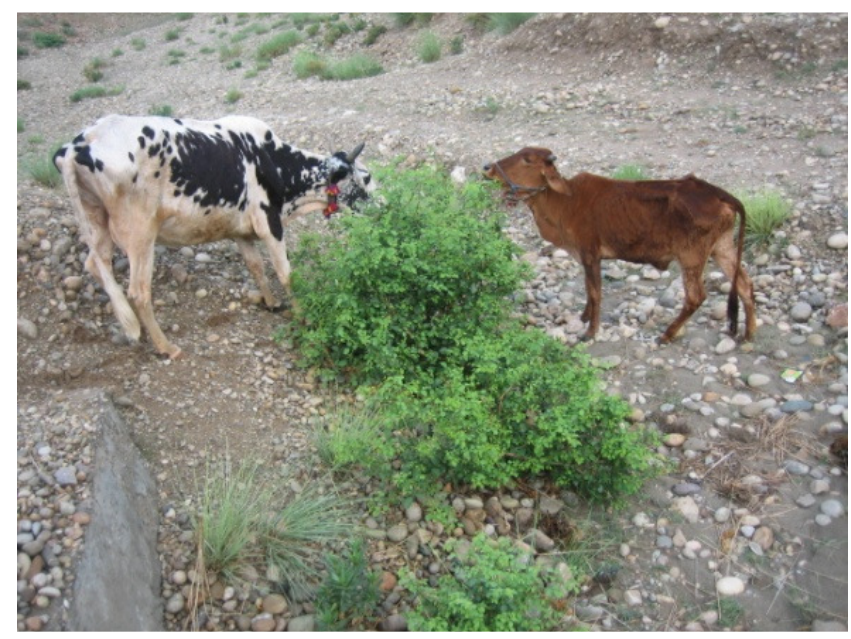

Figure 8. Uncontrolled grazing.

communities and nomads is a complex problem and a major cause of plant extinction. Regarding impacts of unsustainable use of plant species, no accurate information has been published (Davis et al., 1995), but there is no doubt about its consequences. Another major concern is that, local inhabitants and commercial scale poultry farms have no access to the natural gas and electricity for maintaining their living. Fuel wood chopping exercise is quite prominent in the habitat of tree species, thus badly affecting its population and in next decat the rare tree will become vulnerable. Rabinowitz (1981) suggests that those species which are found over a wide geographic range but are consistently rare throughout their distribution need immediate attention as they are more vulnerable from extinction point of view (Figure 7).

Grazing is another ecological problem observed to change the habitat of native flora. Grazing activity was observed in the habitat (Figure 8), but its impact was 


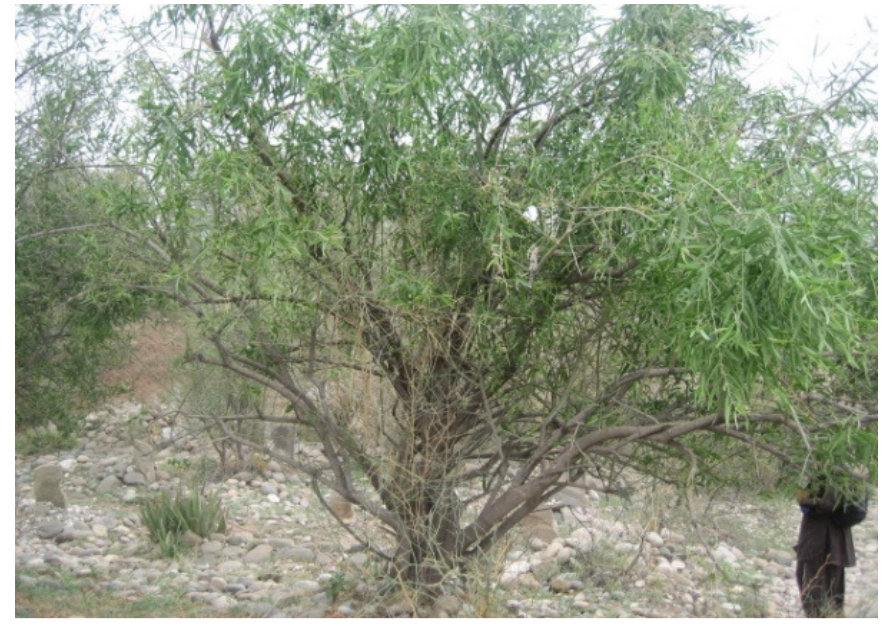

Figure 9. Salvadora oleoides.

quite prominent and devastating for tree species. Uncontrolled and expanding grazing activities have a deep and long term impact on the local vegetation and it is disastrous for the local plant wealth which is already in stress. It was also observed that the erosion was increased proportionally with increasing the grazing. According to Pieper (1994), impact of grazing ranges from almost undetectable removal of plant material to severe depletion of vegetational resources and extensive erosion.

Many threatened plant species are predisposed to threat due to their small population sizes (Rabinowitz, 1981; Kruckeberg and Rabinowitz, 1985). The conservation status of a species was mainly based on the number of mature individuals of some species. The current study was conducted, according to the IUCN red list categories and criteria (Anonymous, 2001), which describes in detail that if population size is fewer than 250 mature individuals with a continuous decline in their number along with no sub-populations, making the tree species eligible to be placed under critically endangered (CR) category. Salvadora oleoides (Figure 9) with a population size of 11 is placed under critically endangered category and is under threat of extirpation. These findings suggest that low population size along with continuous decline in their numbers without having any subpopulations is critical for its survival.

The conservation status of tree species was determined on the basis of geographic range and number of localities. From the point of view of number of localities the $S$. oleoides was reported from single locality in the research area (Figure 10). Based on the small geographic range and single locality, $S$. oleoides was placed under endangered category. According to Anonymous, (2001) the conservation status of a tree species was also based on the geographic range and number of localities/subpopulations. The categories and criteria clearly explain that if a plant species had less than $500 \mathrm{~km}^{2}$, extent of

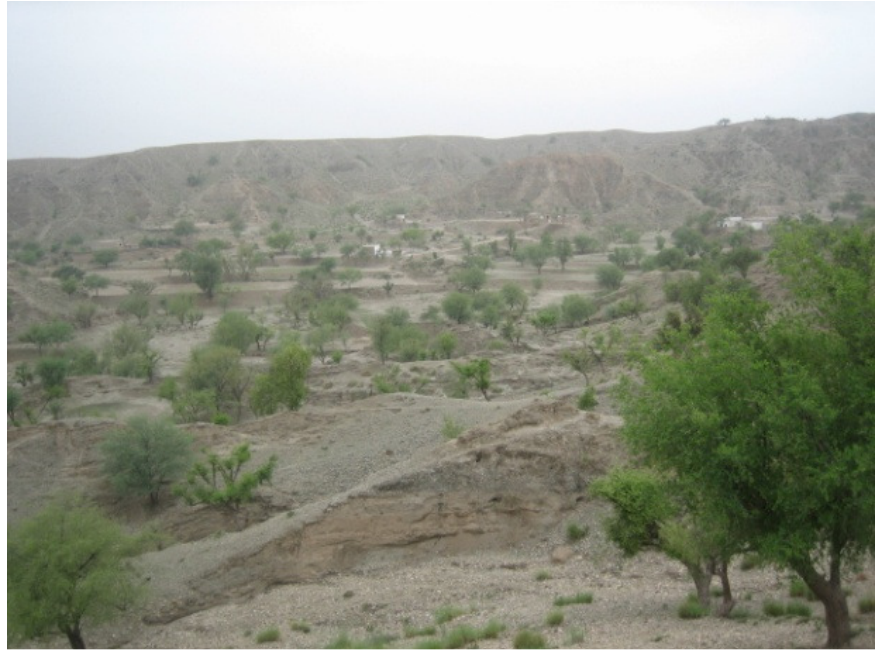

Figure 10. A view of research area.

occurrence with one locality or severely fragmented localities should be considered as endangered (EN) in addition to other parameters. These findings according to IUCN criteria suggest that the restricted distribution range of concerned $S$. oleoides and other rare tree species in a single locality is critical for its survival. On the basis of multiple threats that is, habitat specificity, restricted distribution range, habitat loss through commercial scale stone excavation activities, invasion of invasive species that is, $P$. juliflora over exploitation in the form of grazing and fuel wood cutting and low population size along with negligible natural recruitment, the current study concludes that $S$. oleoides was highly prone to extirpation and eligible to be placed under endangered (EN) category and other rare tree were protected from vulnerable species. In context with global biodiversity, conservation of a rare species at national level is very important. Hence, urgent conservation steps should be taken as suggested below, to avoid its extirpation from Tehsil Takht-e-Nasrati, Pakistan:

1. In the Red Data list of threatened species for Takht-eNasrati, Pakistan the $S$. oleoides should be included.

2. To assign the category in international perspective, conservation status assessment of the $S$. oleoides and other rare tree species in other area of Pakistan should also be initiated.

3. Efforts should be made to protect the $S$. oleoides by minimizing the anthropogenic activities in the habitat (that is, stone excavation, fuel wood cutting, grazing and poultry business).

4. Seeds of the $S$. oleoides and other trees species should be preserved in local seed banks and also distributed to other regional conservation organizations, so that in case of any natural disaster it can be protected and recovered.

5. For the local inhabitants alternate environmentally 
friendly and sustainable jobs should be provided for maintaining their living properly.

6 . To reduce the wood cutting activities in the area alternate means of energy like electricity and natural gas should be provided.

7. In Pakistan, the study of plant conservation status should be done on small scale.

\section{Conclusion}

The method and technique of Hybridization and Grafting should be introduced which will be a good effort in conservation and expansion of many species. A lot of fruits, especially Zizyphus Species, Monotheca buxifolia and Acacia nilotica are wasted annually due to nonavailability of market. Medicinal farm should be set up in the study area to promote the vital importance of the plants and its conservation. The plants should be introduced in botanic gardens for public display.

\section{ACKNOWLEDGEMENTS}

Authors are grateful to the local people of the study area who have revealed precious information about conservation status of plant species.

\section{REFERENCES}

Alam J, Ali SL (2009). Conservation status of Astraglus gilgitensis Ali (Fabaceae): A critically endangered species in Gilgit district, Pakistan. Phyton (Horn, Austria), 48(2): 211-223.

Anonymous (2001). IUCN Red List Categories: Version 3.1. Species Survival Commission. IUCN, Gland, Switzerland and Cambridge, UK.

Anonymous (2008). IUCN Red List of threatened species, www.iucnredlist.org cited on December 27th 2009.

Baggs JE, Maschinski J (2000). Annual report on the long-term research on Purshia subintegra in the Verde Valley for 1999. Report to Arizona Department of Transportation, Phoenix, Arizona, USA.
Chaudhri MN, Qureshi RA (1991). Pakistan's Endangered Flora -II. Pak. Systematics 5(1-2): 1-84.

Davis SD, Heywood VH, Hamilton AC (1995). Centres of Plant Diversity: A guide and strategy for their conservation, Vol. 2 (Asia, Australasia and the Pacific). Cambridge: IUCN.

El-Keblawy A, Al-Rawai A (2007). Impacts of the invasive exotic Prosopis juliflora (Sw.) D.C. on the native flora and soils of the UAE. Plant Ecol. 190(1): 23-35.

Engler M (2008). The Value of International Trade. Traffic Bull. 22(1): 45.

Govaerts R (2001). How many species of seed plants are there? Taxon 50(4): 1085-1090.

Hawksworth DL, Kalin-Arroyo MT (1995). Magnitude and distribution of biodiversity. In: Global Biodiversity Assessment. (Ed.): V.H. Heywood. Cambridge University Press, Cambridge, UK, pp. 107-192.

Hirway I, Goswami S (2007). Valuation of Coastland Resources: The Case of Mangroves in Gujrat. Academic Foundation, India.

Huston MA (1994). Biological Diversity: The Coexistence of Species on Changing Landscape. Cambridge University Press, Cambridge.

Kruckeberg AR, Rabinowitz D (1985). Biological aspects of endemism in higher plants. Annu. Rev. Ecol. Syst. 16: 447-479.

Myers N (1988). Threatened Biotas: "Hotspots" in tropical forests. Environmentalist 8: 1-20.

Nasir YJ (1991). Threatened plants of Pakistan. In: Plant Life of South Asia. (Eds.): S.I. Ali and A. Ghaffar. Shamim Press, Karachi. pp. 229-234.

Noor M, Salam U, Khan MA (1995). Allelopathic effects of Prosopis juliflora Swartz. J. Arid Environ. 31(1): 83-90.

Pallewatta N, Reaser JK, Gutierrez AT (2003). Invasive alien species in South-Southeast Asia: National Reports and Directory of Resources. Global Invasive Species Programme, Cape Town, South Africa.

Pieper RD (1994). Ecological implications of livestock grazing. In: Ecological Implications of Livestock Herbivory in the West. (Eds.): M. Vavra, W.A. Laycock and R.D. Pieper. Society for Range Management, Denver, CO. pp. 177-211.

Rabinowitz D (1981). Seven forms of rarity. In: The Biological Aspects of Rare Plant Conservation. (Ed.): H. Synge. Wiley and Sons Ltd. pp. 205-217.

Sudhersan C, Abo El-Nil M, Hussain J (2003). Tissue culture technology for the conservation and propagation of certain native plants. J. Arid Environ. 54: 133-147. 